\title{
Birinci Sınıf Hayat Bilgisi Dersi Okulumuzda Hayat Ünitesinde Yer Alan Değerlerin İncelenmesi
}

\author{
DOI: 10.26466/opus.760991
}

\author{
Ümit Gözel * Beste Dinçer** \\ * Öğretmen, Aydın Adnan Menderes Üniversitesi \\ E-Posta umit.gozel@adu.edu.tr \\ ORCID: $\quad$ 0000-0002-6391-0998 \\ ** Dr. Öğretim Üyesi, Aydın Adnan Menderes Üniversitesi \\ E-Posta: bdincer@adu.edu.tr \\ ORCID: $\quad \underline{0000-0002-9264-3665}$
}

\section{Öz}

İlkokul çă̆ındaki öğrencilere birey, toplum ve doğa ekseninde temel bilgi, beceri ve değerler kazandırmayı hedefleyen Hayat Bilgisi dersi öğretim programının özel amaçları arasında öğrencilerin aile ve toplumun temel değerlerine sahip olmasının yanı sıra millî, manevi ve insani değerleri yaşantısal hâle getirmesi yer almaktadır (MEB, 2018). Bu çalışma kapsamında misyonu öğrencileri yaşama hazırlamak olan 1. Sinıf Hayat Bilgisi dersi Okulumuzda Hayat Ünitesi'ndeki metin ve görsellerin doküman incelemesi yöntemiyle değerler eğitimi perspektifiyle incelenmesi amaçlanmıştır. Bu temel amaç doğrultusunda Hayat Bilgisi dersi kapsamında verilen değerlerin metin ve görsellerdeki varlığı ve sıklık derecesi belirlenerek ünite içerisindeki dağılım ve oranlarının tespit edilmiştir. Bu araştırmanın çalışma grubunu 2017-2018 Ĕ̆itim-Öğretim Yılında yenilenen öğretim programları kapsamındaki Talim ve Terbiye Kurulu Başkanlı̆̆ı tarafindan kabul edilen 1. Sinıf Hayat Bilgisi ders kitabının bir ünitesi oluşturmaktadır. Nitel araştırma deseninde gerçekleştirilen bu çalışmada veriler doküman analizi yöntemi ile incelenmiş̧ir. Araştırma bulguları, İlkokul 1. Sınıf Hayat Bilgisi dersi Okulumuzda Hayat Ünitesindeki metin ve görsellerin yüzde ve frekansları incelendiğinde en çok yer verilen değerlerin sırasıyla saygl $(\% 28,9)$, sevgi $(\% 15,7)$ ve sorumluluk $(\% 11,5)$; en az vurgulanan değerlerin ise sabır $(\% 2,4)$, dostluk $(\% 2,4)$, çalışkanlık $(\% 1,6)$ ve adalet $(\% 0,8)$ değerlerinin olduğunu göstermektedir. Ek olarak öğrencilere örtük olarak aktarılması hedeflenen bazı kök değerlerin programda yer almasına rağmen, metin ve görsellerde yer almadığı ortaya konulmuştur.

Anahtar Kelimeler: Değer, değerler eğitimi, hayat bilgisi dersi. 


\title{
Investigation of the Values in the Life Unit in Our First Class Life Science Course

\author{
*
}

\begin{abstract}
The specific objectives of the Life Science course curriculum, which aims to provide primary school students with basic knowledge, skills and values in the context of individuals, society and nature, include making the national, spiritual and human values livable as well as having the core values of the family and society $(M E B, 2018)$. Within the scope of this study, it was aimed to examine the text and visuals in the Life Unit in our School, which is the mission of preparing students for life, with a document analysis method. With this main purpose distribution and proportions of the values given in the field of Life Studies lesson within the unit by determining the degree of frequency and outside the text and images were determined. The study group of this research is composed one of the units of the $1^{\text {st }}$ Class Life Science course book accepted by the Board of Education and Discipline within the scope of the curriculum renewed in 2017-2018 academic year. In this study, which was carried out in a qualitative research design, the data were analyzed by document analysis method. When the percentage and frequency of the text and images in our School Life Unit were analyzed, the most frequently used values were listed orderly as respect $(28.9 \%)$, love $(15.7 \%)$, and responsibility $(11.5 \%)$ and also the least emphasized values were found as patience, friendship (2.4\%), hardworking (1.6\%) and justice $(0.8 \%)$ values. In addition, although some of the root values that are intended to be transferred to students implicitly are included in the program, it has been demonstrated that they are not included in the text and images.
\end{abstract}

Keywords: Values, values education, life science course. 


\section{Giriş}

Küresel dünyada teknoloji, bilim ve iletişim sektörlerindeki baş döndürücü bir hızla yaşanan değişim ve gelişimlerin insan hayatını ve toplum yapısını derinlemesine etkilediği bir gerçektir.

İnternet ulaşımının olduğu her yerde bilgiye ulaşmanın bir tıkla mümkün olduğu bir dünyada yaşadığımız söylenebilir. Fiziksel anlamda yer değiştirmeden oturduğumuz yerden sanal ortamda istediğimiz kütüphaneye girerek istediğimiz bilgiye ulaşabilir, konferanslara ya da online derslere ve kurslara katılabilir, müzeleri dolaşabilir, istediğimiz kitabı ya da dergiyi okuyabilir, dilediğimiz filmi istediğimiz kadar ve istediğimiz zaman izleyebiliriz. Kısacası mevcut dünyanın sınırlarını saniyeler içinde geçebilecek bir çağda yaşadığımızı söylemek mümkündür. Ancak bu durumun, yaşam şartlarının beraberinde bir takım sorunları da getirdiği bir gerçektir.

Bu sorunların başında aile bağlarının zayıfladığı, kadına şiddetin had safhaya çıtığıl, iş ahlakında bir düşüşün yaşandığı, gençlerde uyuşturucu, bağımlılık, şiddet olaylarının görülme sıklı̆̆ının artması gibi medyada dünya genelinde pek çok haberin çıktığı görülmektedir (Aslan ve Aybek, 2019). Bu sorunların temel nedenlerinden birinin değerlerinden uzak bir şekilde büyüyen bir neslin olduğu söylenebilir. İşte tam bu noktada değerler eğitimi son derece önem kazanmaktadır. Değerler, dünyada yaşayan tüm insan topluluklarının bir arada huzur ve refah ortamında yaşamalarını sağlayan, yaşamı kolaylaştıran, örf ve adetler gibi yazılı olmayan kurallar bütünü olarak tanımlanabilir. Değerler eğitimi ise literatürde farklı şekillerde sınıflandırılan milli, ahlaki, evrensel, dini, sosyal vb. değerlerin öğrencilere aktarılması ve kazandırılması olarak tanımlandırılabilir.

Son zamanlarda yapılan çalışma ve araştırmalar incelendiğinde "değerler eğitimi"nin sıklıkla her alanda çalışılan bir konu olduğunu görülmektedir. Özellikle 2000'li yıllar sonunda Avustralya, ABD, Japonya, Endonezya ve Türkiye (Abu, Mockhtar, Hassan ve Suhan, 2015; Akbaş, 2008; Bradly, 2011; Dally, 2010; Dill, 2007; Halil, 2003; Hashim ve Langgulung, 2008; Kulaks1zoğlu ve Dilmaç, 2000; Marshall, Caldwell ve Foster, 2011; Noddings, 1994; Raihani, 2011; Roessgaard, 2011, 2016; Sj, 1990; Tudball, 2007; Ulusoy ve Dilmaç, 2012) gibi ülkelerin değerler konusuna ayrı bir ihtimam gösterdiği, 
mevcut programlarını revize ederek öğretim programlarına Değerler Eğitimini dahil ettikleri ya da ayrı bir program olarak öğrencilerine aktardıkları bu konunun önemini ortaya koymaktadır.

Değerler eğitimi Türkiye' de yeni uygulanan ve programlara dahil edilen bir özellik olarak anlaşılmamalıdır. Çünkü 2005, 2009, 2015 yılı itibariyle geçmiş yıllarda ve son olarak (2017 Taslak Öğretim Programı) ve 2018 Öğretim Programları içeriğinde değerler eğitiminin öğretim programlarında yer ald1ğını görmek mümkündür.

Şöyle ki yapılan doküman incelemeleri sonucunda değer sayısı, değer adı ve değerlerin bulunduğu başlıklar değişse de 2005 yılından bu güne değerler eğitiminin öğretim programlarında yer aldığını göstermektedir (Gözel, 2018; Yaşaroğlu, 2018). Örneğin 2005 ve 2009 yıllarında uygulananan Hayat Bilgisi Öğretim Programı incelediğinde değerler konusunun Kişisel Nitelikler başlığı altında (MEB, 2005, 2009), 2015 Hayat Bilgisi Öğretim Programlarında ise değerler başlığı altında yer aldığı görülmektedir (MEB, 2015). 2017 Hayat Bilgisi Taslak Öğretim Programı (MEB, 2017) ve özellikle 2018 Hayat Bilgisi Öğretim Programları incelendiğinde ise değerlerin Değerler başlı̆̆1 altında (MEB, 2018) yer aldığ1 ve özel bir hassasiyetle tüm öğretim programlarının revize sebeplerinden biri olarak ifade edildiği belirtilmektedir.

2017-2018 öğretim programlarının vizyonu, yaklaşımı, yetkinlikler ve genel anlamda değişim sebebi incelendiğinde ilköğretim düzeyindeki tüm derslerde değer öğretiminin ön plana çıktığı açıkça ifade edilmektedir. Tüm öğretim programlarında yeralan değerler ve değerler eğitiminin özellikle örtük programla verilmesi gerektiği hususu beyan edilmiştir (MEB, 2017). Bu sebeple resmi program dışında öğrenmelerin gerçekleştirilmesine olanak sağlayan örtük program kaynakları (okulun idari/ örgütsel araç ve düzenlemeleri, okul-çevre arasındaki etkileşimler ve sınıf iklimi) oldukça önemlidir. Örtük programın kaynağını oluşturan temel kaynaklar incelendiğinde, okul kuralları, okul binasının mimarisi ve dekarasyonu, sınıfların oluşturulması, ders dişı faaliyetler, toplumsal norm ve değerler, ideoloji, ders kitapları, öğretmenlerin görüş ve beklentileri, öğretmenlerin ön yargıları, sınıf kuralları, öğretmen davranışları, öğrenci özellikleri, sınav ve öğrenci başarı olarak karşımıza çıkmaktadır (Tezcan 2003; Yüksel, 2002, 2004, 2005). Bu göstergeler öğrencinin okula adım atışından okulu terk edişine kadar olan zaman içerisinde resmi program dışındaki bütün alan, konu, kişi, şahıs vb. durum ve olayların 
örtük programın bir ayağını oluşturduğunu göstermektedir. Dolayısıyla ilkokul öğrencilerinin birçok temel beceri ve yetkinliğin yanı sıra değer kazandığı ve yaşama hazırlık anlamında hem öğrencilere hem de öğretmenlere temel bir ders kitabı niteliğinde hizmet eden Hayat bilgisi ders kitabında, değerlerin aktarımının tesadüflere bırakılmadan kasıtlı yapılabileceği metinlere yer verilmesi ve bu konuda öğretmenlerin de bilgilendirilmesi gerekmektedir.

İlköğretimde düşünce temelinin, öğrencinin mümkün olduğunca eşyaya yaklaştırılması, eşyayı gözlemlemesi ve kullanması gerektiği görüşünü ileri süren Eflatun'a kadar dayandığı söylenebilen ve hayatın içinden örnekler sunan Hayat bilgisi dersi (Baysal, Tezcan ve Araç, 2016) öğretim programı ve ders kitaplarının incelenmesi sürecin işleyişi açısından gerekli görülmektedir. Ders kitapları hazırlanırken kazanımların belirlenmesi, içerik, konu seçimi ve görsellerin öğrencilerin yaş ve gelişim özelliklerine göre seçilmesi önemlidir. Bireyleri gerçek hayata hazırlık olarak algılanan ve böyle bir misyonunun olduğu ifade edilen bir derste metinlerin seçiminde de dersin özel amaçları, genel amaçları, temel becerileri, konu alanları ve değerler dikkate alınarak seçilmesi önemli olduğu düşünülmektedir.

Bu alanda yapılan çalışmalar incelendiğinde program paydaşlarıyla yapılan görüşmelerin yanı sıra (Ak Tefek, 2016; Bahçe, 2010; Çanak, 2019; Dinçer ve Gözel, 2018; Eryılmaz, 2016; Narin, 2007; Sever, 2015; Özleşmiş, 2019) Hayat bilgisi öğretim programlarının ve ders kitaplarının farklı yıllarda değerler açısından irdelendiği görülmektedir (Akyol, 2018; Bal, 2019; Balık, 2016; Bayırlı, 2018; Bölük, 2018; Candan ve Ergen, 2014; Demir, 2018; Demir ve Demirhan İşcan, 2007; Gözel, 2018; Gündüz, 2014; Güzel, 2013; Kale, 2015; Koç, 2020; Kurt, 2019; Küçük, 2016; Özkan, 2017; Öztürk ve Özkan, 2018; Sude, 2017; Uçar, 2019; Yaşaroğlu, 2013, 2018).

Bu çalışma kapsamında daha özele inilerek misyonu öğrencileri yaşama hazırlamak olan 1. Sınıf Hayat Bilgisi dersi Okulumuzda Hayat Ünitesi'ndeki metin ve görsellerin doküman incelemesi yöntemiyle değerler eğitimi perspektifiyle incelenmesi ve Hayat Bilgisi öğretim programıyla karşılaştırılması amaçlanmıştır. Bu sayede metinlerde her bir değer cümle bazında ifadelendirilerek program uygulayıcısı olan öğretmenlere ve değerler eğitimiyle ilgili hazırlanacak kaynakların hazırlanmasına katkıda bulunmak istenmiştir. 


\section{Araştırmanın Amacı}

Bu çalışmanın temel amacı 1. Sınıf Hayat Bilgisi dersi Okulumuzda Hayat Ünitesi'ndeki metin ve görsellerin değerler açısından incelenmesidir. Bu temel amaç doğrultusunda Hayat Bilgisi dersi kapsamında verilen değerlerin metin ve görsellerdeki varlığı ve sıklık derecesi belirlenerek ünite içerisindeki dağılım ve oranlarının tespit edilmesi amaçlanmış ve aşağıdaki sorulara cevap aranmiştır.

1. İlkokul 1. Sinıf Hayat Bilgisi ders kitabı Okulumuzda Hayat Ünitesi'ndeki metin ve görsellerde yer alan değerler ve ifade biçimleri nelerdir?

2. İlkokul 1. Sınıf Hayat Bilgisi öğretim programında yer alan ve Okulumuzda Hayat Ünitesi'ndeki metin ve görsellerde örtüşen değerler nelerdir?

\section{Araştırmanın Modeli}

Nitel araştırmada, gözlem ve görüşme gibi veri toplama yöntemlerini kullanarak algıların ve olayların doğal ortamda gerçekçi ve bütüncül bir şekilde ortaya konması amaçlanır (Yıldırım ve Şimşek, 2008). İlkokul 1.Sınıf Hayat Bilgisi dersi Okulumuzda Hayat Ünitesi'nde yer alan değerlerin tespiti ve değerlendirilmesi amacıyla yapılan bu araştırma nitel çalışma deseninde tasarlanmış olup veriler doküman analizi yöntemi ile toplanmıştır.

\section{Çalışma Grubu}

Nitel araştırma temelli yapılan çalışmalarda araştırmacının amacı evrene genellemek değil ana sorunu derinlemesine incelemektir. Bu sebeple araştırmacı mevzunun daha iyi idrak edilmesi için amaçlı olarak veya isteyerek çalışma grubunu belirleyebilmektedir (Creswell, 2012).

Bu araştırmanın çalışma grubunu 2017-2018 Eğitim-Öğretim Yılında yenilenen öğretim programları kapsamındaki 1. Sınıf Hayat Bilgisi Ders Kitabı oluşturmaktadır. Metin ve görsellerin derinlemesine incelenmesi amaçlandığ için ölçüt örneklemeden faydanılmış ve bu doğrultuda çalışmaya 1. Sınıf Hayat Bilgisi Ders Kitabındaki Okulumuzda Hayat Ünitesi dahil edilmiştir. Okulumuzda Hayat Ünitesinin Hayat Bilgisi ders kitabının ilk ünitesi olması, 
öğrencilerin kitapla ve okulla (Okulda Hayat Ünitesi) tanışacağı ilk ünite olması gibi sebeplerden dolayı örnekleme dahil edilmiştir.

\section{Veri Toplama Aracı}

Araştırmaya ilişkin veriler, araştırmacı tarafından oluşturulan kontrol listesi ile toplanmıştır. Kontrol listesinin oluşturulma ve yapılandırılma sürecinde değerler eğitimi ve hayat bilgisi ile ilgili literatür taraması yapılmış, ilgili araştırmalar, tezler incelenmiş ve iki konu alanı uzmanı tarafından onaylandıktan sonra kontrol listesinin son şekli oluşturulmuştur. Formun pilot uygulaması "Hayat Bilgisi dersi Öğretim Programının Değerler Eğitimi Açısından Öğretmen Görüşlerine Göre Değerlendirilmesi" (Gözel, 2018) adlı tez çalışmasında 1., 2. ve 3. Sınıf hayat bilgileri derslerindeki kazanımlarda yer alan değerlerin incelenmesinde kullanılan kontrol listesinin geliştirilerek yapılandırılması sonucu oluşturulmuştur. Kontrol listesi toplamda 22 değerden meydana gelmektedir.

\section{Verilerin Toplanması ve Analizi}

Nitel araştırma deseni benimsenerek gerçekleştirilen bu çalışmada veriler araştırmanın amacı ile ilgili bilgileri kapsayan yazılı ve görsel materyallerin analiz edilmesine dayalı olarak doküman incelemesi yöntemi ile incelenmiştir. Doküman incelemesi, araştırılacak konu ya da araştırma probleminin belirli zaman içerisinde üretilmiş dokümanlar, konuyla ilgili birden fazla kaynak ve farklı zaman aralıklarında üretilmiş dokümanların geniş bir zamana dayalı olarak incelenmesine olanak sağlamaktadır (Yıldırım ve Şimşek, 2002, 2005).

Dokümanlar, bir çalışmanın parçası ya da tamamı olarak çeşitli şekillerde ve amaçlarda kullanılabilirler. Bu çalışmada doküman incelemesi programda doğrudan gözlemlenemeyen ayrıntıların ortaya çıkarılması amacıyla kullanilmıştır.

Doküman analizi yüzeysel ve derinlemesine inceleme, yorumlamayı içeren bir süreçtir. Bu yinelemeli süreç, içerik analizi ve tematik analiz öğelerini birleştirmektedir. İçerik analizi, araştırmanın temel soruları ile ilgili kategorilerdeki bilgileri düzenleme sürecidir (Bowen, 2009). Bu süreçte araştırmanın verileri betimsel analiz ve içerik analizi ile incelenmiştir. İçerik analizinde bir- 
birine benzeyen veriler benzer kavram, tema ve kod çerçevinde bir araya getirilerek anlaşılır bir biçimde yorumlanmıştır (Yıldırım ve Şimşek, 2011). Betimsel analiz kapsamında değerlerin tespiti ve ifadesi metinler ve görsellerden doğrudan alıntılar yapılarak gerçekleştirilmiştir.

\section{Araştırmanın Geçerliliği ve Güvenirliği}

Nitel araştırmada, örneklem genellikle araştırma soruları ve incelenecek olan olay doğrultusunda amaca yönelik olarak seçilmektedir. Dışsal geçerliliğin sağlanmasında önemli olan, örneklemin araştırma evrenini temsil etmesi değil; araştırma yapılacak olaya uygunluğudur (Maxwell, 1992). Dış geçerliliğini sağlamak için ölçüt olarak ele alınan ünite, amaç kümesine uygun olarak seçilmiş ve çalışma grubu, veri toplama ve analiz süreçleri detaylı olarak açıklanmıştır.

Glesne ve Peshkin (1992), kalitatif çalışmaları uzmanlarla paylaşmanın ve onlardan geribildirim almanın çalışmanın güvenilirliğini artıracağını belirtmiştir. Bu kapsamda kodlamalarda doktora derecesine sahip iki konu alanı uzmanından yardım alınmıştır. Roberts ve Priest (2006), verilerin bağımsız bir araştırmacının gönderilebileceğini ve analizlerden geribildirim alınabileceğini vurgulamıştır. Ayrıca çalışmanın güvenilirliğini sağlamak ve arttırmak amaciyla elde edilen bulgular, nitel araştırma alanında doktora ünvanına sahip bağımsız bir araştırmacıya gönderilmiş ve geri bildirim alınmıştır. Ek olarak Le Compte ve Goetz (1982, Akt.Yıldırım ve Şimşek, 2006) aktardığı üzere metinlerde yer alan değerler ve görseller betimsel bir yaklaşımla doğrudan sunularak iç güvenirlik sağlanmıştır.

Miles ve Huberman'a (1994) göre, nitel araştırmalarda kodlamanın güvenirliğini ve geçerliliğinin sağlamak oldukça önemlidir. İç tutarlılık olarak adlandırılan güvenirlik değeri hesaplamasında \%80'in üzerinde değer çıktığında, analiz güvenilir kabul edilmektedir. Bu değer (Güvenirlik: Uzlaşma Sayısi/Uzlaşma+Uzlaşmama Sayısı) her oluşturulan kategori için oluşturulur.

Araştırmacı ve farklı iki uzman tarafından yapılan farklı kodlamalar ve yorumlara bakıldığında, ayrıca bağımsız bir araştırmacını yaptığı kodlamalar sonucunda güvenirlik hesaplaması \% 85 bulunduğu için bu çalışma güvenilir olarak kabul edilmiştir.

Duyarlılık değeri (kültürel mirasa duyarlılık ve toplumsal duyarlılık alt değeri), saygı değeri (farklılıklara saygı, İstiklal Marşı́na saygı, değerlere 
saygı ve başkalarına saygı alt değeri), sevgi değeri (bayrak sevgisi, okul sevgisi, insan sevgisi ve vatan-millet sevgisi alt değeri) ve sorumluluk değeri (üzerine düssen görevleri yerine getirme alt değeri) şeklinde alt değer şeklinde ifadelendirilmelerinden dolayı görüş birliğine varılarak kodlanmıştır.

\section{Bulgular ve Yorum}

İlkokul 1. Sınıf Hayat Bilgisi ders kitabı Okulumuzda Hayat Ünitesi'ndeki metin ve görsellerde yer alan değerler ve ifade biçimleri

Bu bölümde, İlkokul 1. sınıf Hayat Bilgisi ders kitabı Okulumuzda Hayat Ünitesi'sinin doküman incelemesi sonucu elde edilen veriler aktarılmış ve bu verilerin yorumları yapılmıştır. İlkokul 1.sınıf Hayat Bilgisi ders kitabı Okulumuzda Hayat Ünitesinde yer alan değerlerin frekanslarına ve yüzdelerine ilişkin bulgular Tablo 1'de verilmiştir:

Tablo 1. İlkokul 1. Sını Hayat Bilgisi Ders Kitabı Okulumuzda Hayat Ünitesindeki Değerlerin Frekans ve Yüzde Değerleri

\begin{tabular}{lllll}
\hline \multirow{2}{*}{ Değer Adı } & $\mathbf{F}$ & $\mathbf{0}$ & Metin İçi & Görsel \\
\cline { 4 - 5 } & & & İfade & İfade \\
\hline Sayg1 & 35 & 28,9 & 7 & 18 \\
\hline Sevgi & 19 & 15,7 & 9 & 12 \\
\hline Sorumluluk & 14 & 11,5 & 9 & 1 \\
\hline Güven & 10 & 8,2 & 5 & 4 \\
\hline Duyarlılık & 9 & 7,4 & 4 & 5 \\
\hline Vatanseverlik & 9 & 7,4 & 2 & 6 \\
\hline Bağımsılık & 8 & 6,6 & 6 & 2 \\
\hline Yardımseverlik & 8 & 6,6 & 1 & 2 \\
\hline Dostluk & 3 & 2,4 & - & 3 \\
\hline Sabır & 3 & 2,4 & 1 & 1 \\
\hline Çalıskanlık & 2 & 1,6 & - & 60 \\
\hline Adalet & 1 & 0,8 & 61 & \\
\hline TOPLAM & 121 & 100 & & 1 \\
\hline
\end{tabular}

Tablo 1'de görüldügüü üzere ilkokul 1. Sınıf Hayat Bilgisi dersi Okulumuzda Hayat Ünitesindeki metin ve görsellerin yüzde ve frekansları incelendiğinde en çok yer verilen değerin 35 kez tekrar eden "saygı" (\%28,9), 19 kez tekrar eden "sevgi" $(\% 15,7)$ ve 14 kez tekrar eden "sorumluluk" $(\% 11,5)$ değerinin olduğu tespit edilmiştir. 
Metin ve görsellerde en az vurgulanan veya en az yer verilen değerlerin üç kez tekrar eden "sabır" ve "dostluk" (\%2,4), iki kez tekrar eden "çalışkanlık" $(\% 1,6)$ ve bir kez tekrar eden "adalet" $(\% 0,8)$ değerlerinin olduğu görülmüştür.

Tablo 1 ile belirtilen 1. Sinıf Hayat Bilgisi dersi Okulumuzda Hayat Ünitesinde yer alan her bir değere ilişkin analizler aşağıdaki gibidir:

Bağımsızlık: Tablo 1'deki verilere göre, bağımsızlık değeri 1. Sınıf Hayat Bilgisi ders kitabı Okulumuzda Hayat Ünitesindeki metinlerde iki ayrı yerde, görsellerde ise iki ayrı yerde bulunmaktadır. Metinlerde yer alan bağımsızlık değeri, "Bayrağımız ve İstiklal Marşı' mız" konu başlığı altında "Bayrağımız ve İstiklal Marşı'mız bağımsızlığımızın sembolüdür." (s.27) ve ünite değerlendirme sorularında "Hangisi bağımsızlığın sembolüdür?" (s.56) ifadeleriyle yer almaktadır.

Görsellerde yer alan bağımsızlık değerine ilişkin görsel ifadelerden bir örnek alıntı aşağıdaki gibidir:

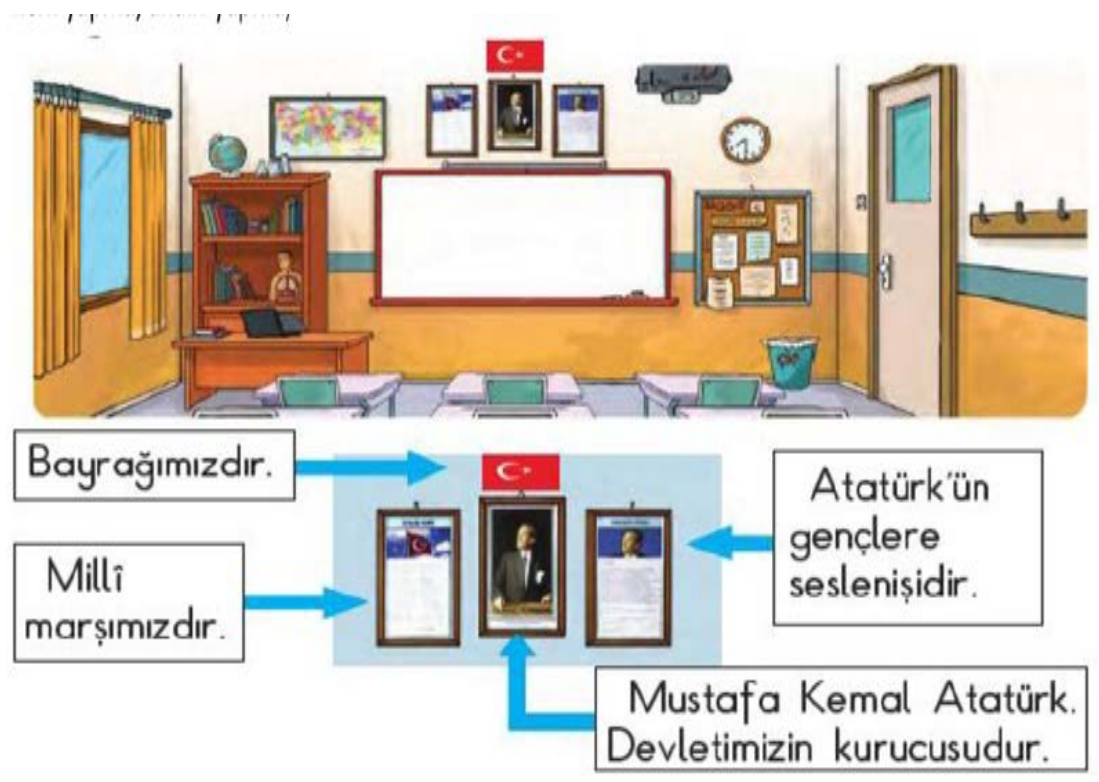


Bu görsel ifadede bağımsızlık değeri resmedilmiştir. Resimde bayrağımı, milli marşımız, Atatürk'ün gençlere seslenişi ve Atatürk resimleri görülmektedir. Vatan, bayrak, Atatürk ve Atatürk'ün gençlere seslenişi üzerinden bağımsızlık değerine vurgu yapıldığı ifade edilebilir.

Çalışkanlık: Tablo 1'deki bulgular ışığında, çalışkanlık değeri 1. Sınıf Hayat Bilgisi ders kitabı Okulumuzda Hayat Ünitesindeki metinlerde tek bir yerde bulunduğu düşünülmektedir. Bu değere "Etkinliklere Katılıyoruz" konu başlığı altında "Arkadaşlar, kulübümüzün atık pil toplama projesinde kimler görev almak ister ?" (s.48) ifadesiyle vurgu yapılmıştır. Çalışkanlık değeri görsellerde de sadece tek bir yerde bulunduğu tespit edilmiştir. Görselde yer alan çalışkanlık değerine ilişkin göresel ifade aşağıdaki gibidir:

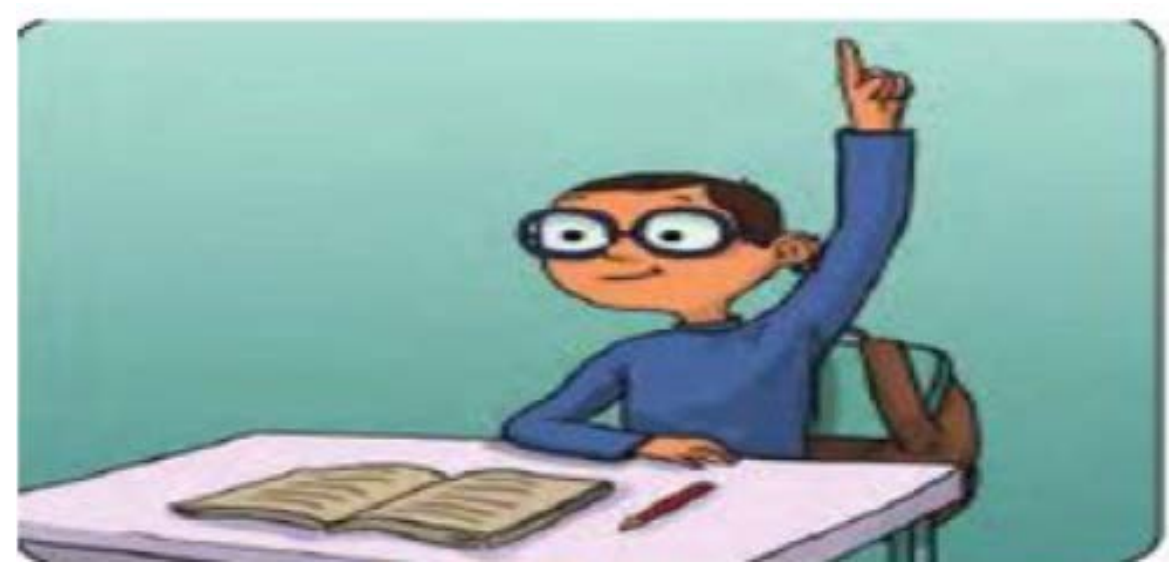

"Kurallar Her Yerde" (s.39) konu başlığı altında yer alan bu görsel ifadede çalışkanlık değeri resmedilmiştir. Görsel ifadeden de anlaşılacağı üzere dersini dinleyen, derse katılan düzenli, temiz ve dikkatli bir öğrencinin varlığ temsil edilerek çalışkanlık değerine vurgu yapılmıştır. Ayrıca öğrencinin ders araç ve gereçlerini masasının üzerinde düzenli bir şekilde tutması çalışkanlık değerine vurgu yapıldığını gösterir niteliktedir.

Duyarlılık: Tablo 1'deki bulgulara göre, Duyarlılık değeri 1. Sınıf Hayat Bilgisi ders kitabı Okulumuzda Hayat Ünitesindeki metinlerde beş farklı yerde bulunduğu düşünülmektedir. Duyarlılık değeri içerisinde üç adet toplumsal 
duyarlılık alt değeri ve iki adet kültürel mirasa duyarlılık alt değerleri yer almaktadır. Toplumsal duyarlılık 1. Sınıf Hayat Bilgisi ders kitabı Okulumuzda Hayat Ünitesinde farklı yerlerde verilen cümlelerle tekrarlanmıştır. "Farklıyız, Farkındayız" konu başlığı altında "İşitme cihazın düşmüş. Az kalsın basacaktım." (s.15)/ "Güvenli Yolları Biliriz" konu başlığı altındaki değerlendirme sorularında "Okul yolunda tanıdığım kişilerle selamlaşırım" (s.22) / "Kurallar Her Yerde" konu başlığı altında "Sınıf kurallarımız olmasaydı ne olurdu?" ifadeleriyle yer almaktadır. Kültürel mirasa duyarlılık 1. Sınıf Hayat Bilgisi ders kitabı Okulumuzda Hayat Ünitesinde farklı yerlerde verilen cümlelerle tekrarlanmıştır. "Ünite Değerlendirme Soruları" konu başlı̆̆ı altında bulunan "Atatürk resminin solunda ne var, Atatürk resminin üzerinde ne var?" (s.59) ifadeleriyle yer almaktadır.

Duyarlılık değerinin görsellerde dört farklı yerde olduğu düşünülmektedir. Duyarlılık değerinin yer aldığı görsel ifadelerden örnek resim aşağıdaki gibidir:

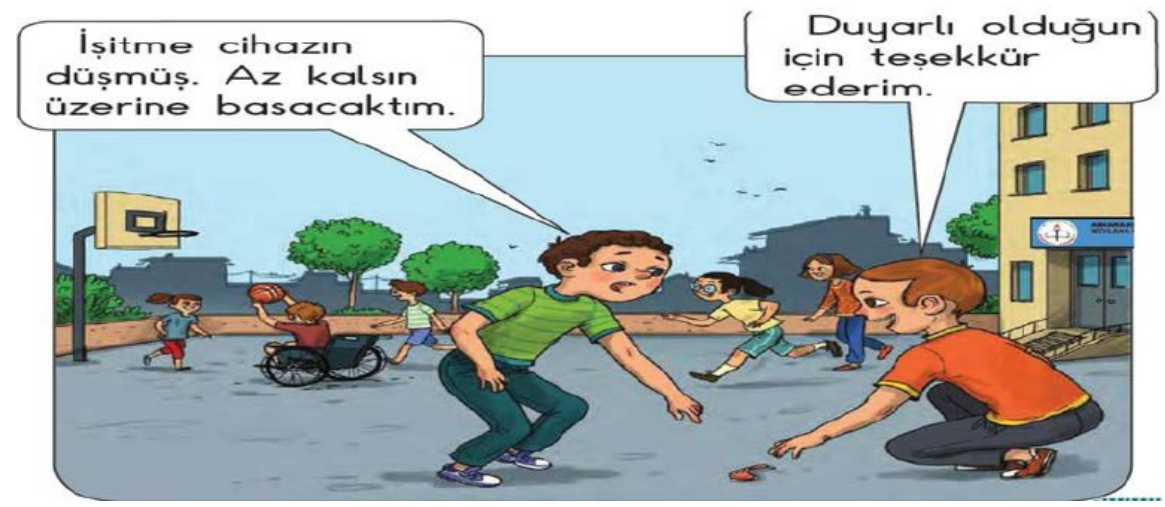

Bu görsel ifadede duyarlılık değeri resmedilmiştir. İnsanların birbirlerine duyarlı olduğu/olması gerektiği görselde resmedilmeye çalışılmış, insanların birbirlerine daha duyarlı olmaları gerektiği hususu yukarıda yer alan görselle desteklenerek vurgulanmıştır.

Dostluk: Tablo 1'deki bulgulara göre, dostluk değeri 1. Sınıf Hayat Bilgisi ders kitabı Okulumuzda Hayat Ünitesindeki metinlerde tek bir yerde olduğu düşünülmektedir. "Tanışıyoruz" konu başlığı altındaki "Merhaba" 
isimli şiirin dördüncü mısrasında "Dost olalım mı?" (s.12) ifadesiyle yer almaktadır. Görsellerde ise iki farklı yerde dostluk değerinin bulunduğu düşünülmektedir. Dostluk değerinin yer aldığı görsel ifadelerden örnek resim aşağıdaki gibidir

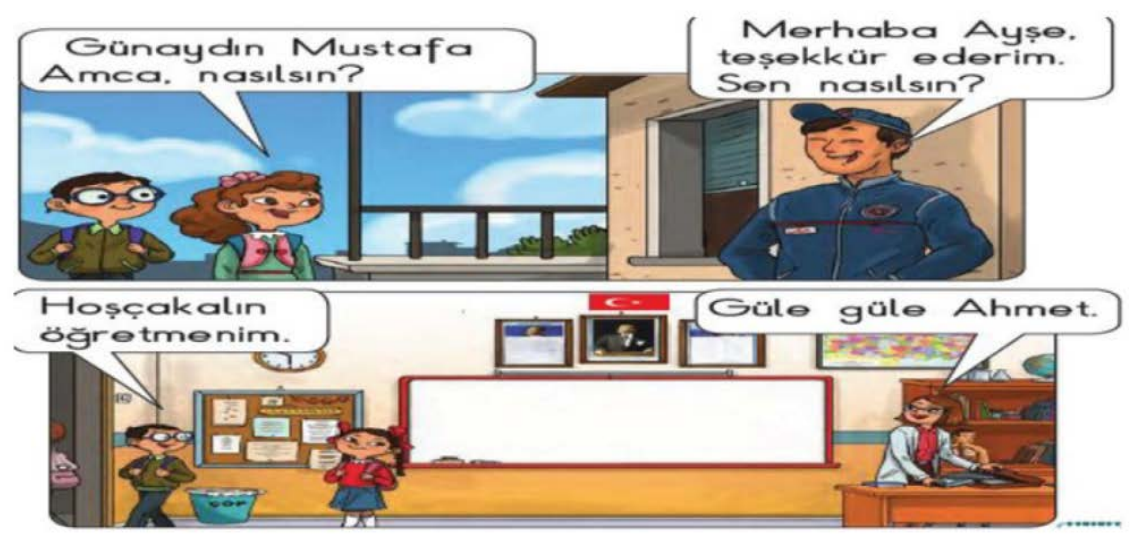

Bu görsel ifadede dostluk değeri resmedilmeye çalışılmıştır. İnsanların tanıdıklarına, arkadaşlarına veya dostlarına selam vermesi, onların hal ve hatırlarını sorması ve yoldan geçerken bir selam vermesi dostluğun bir nişanesi olarak değerlendirilebilir.

Güven: Tablo 1'deki bulgulara göre, güven değeri 1. Sınıf Hayat Bilgisi ders kitabı Okulumuzda Hayat Ünitesindeki metinler içerisinde dokuz ayrı yerde olduğu düşünülmektedir. Örnek vermek gerekirse bu değer “Farklıyız, Farkındayız" konu başlığı altında "Okul yolunda hangi durumlar bizim için tehlikeli olabilir?" (s.16) ifadesiyle / "Güvenli Yolları Biliriz" konu başlığı altında yer alan değerlendirme sorularında, "Tanımadığım kişiler çağırdığında yanlarına gitmem." ifadesiyle, "Ailemin bilgisi olmadan, tanıdığım ya da tanımadığım kişilerle okula gitmem." ifadesiyle, "Tanıdığımız ve tanımadığımız kimselerle iletişim kurarken nelere dikkat etmeliyiz?" (s.22) ifadesiyle yer almaktadır. Görsellerde ise sadece bir yerde güven değerine ilişkin değere rastlanmıştır. Güven değerinin yer aldığı görsel aşağıdaki gibidir: 


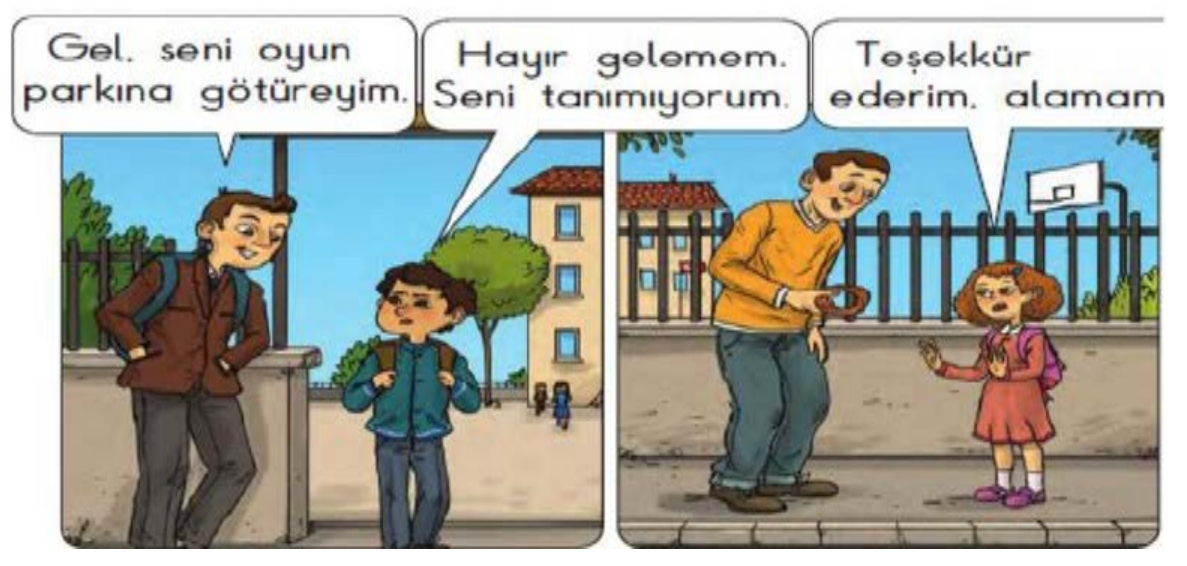

Bu görsel ifadede güven değeri yer almaktadır. Özellikle okul çıkışında, okul girişinde veya sokakta tanımadığı insanların verdiğinin alınmaması, tanımadığı/bilmediği insanların isteklerinin yerine getirilmemesi gerektiği resmedilmeye çalışılarak güven duyulacak kişilerin doğru seçiminin yapılması gerektiği vurgulanmaya çalışılmıştır.

Saygi: Tablo 1'deki bulgulara göre, saygi değeri 1. Sınıf Hayat Bilgisi ders kitabı Okulumuzda Hayat Ünitesindeki metinlerde 17 farklı yerde olduğu düşünülmektedir. Saygı değeri içerisinde farklılıklara sayg1 (4), bayrağa sayg1 (6), İstiklal Marşı'na saygı (5), değerlere saygı (1) ve başkalarına saygı (1) alt değerleri yer almaktadır. Farlııklara saygı değeri 1. Sınıf Hayat Bilgisi ders kitabı Okulumuzda Hayat Ünitesinde farklı yerlerde verilen cümlelerle tekrarlanmıştır. "Farklıyız, Farkındayız" konu başlığı altında "Özel gereksinimi olan arkadaşlarımıza nasıl davranmamız gerektiğini belirtelim." (s.15) ifadesiyle / "Yanımızdaki arkadaşlarımızla farklı yönlerimizi söyleyelim." İfadesiyle (s.16) ifadesiyle yer almıştır. Bayrağa saygı değeri 1. Sınıf Hayat Bilgisi ders kitabı Okulumuzda Hayat Ünitesinde farklı yerlerde verilen cümlelerle tekrarlanmıştır. "Bayrağımız ve İstiklal Marşı'mız." konu başlı̆̆1 altında "Bayrağımıza ve İstiklal Marşı́mıza saygı göstermeliyiz. Bayrak töreninde yüzümüzü bayrağımıza dönmeliyiz ve konuşmamalıyı.." (s.27) ifadesiyle / "Bayrak töreninde yüzümüz bayrağımıza dönük olmalıdır." (s.28) İfadesiyle, "Ünite Değerlendirme Soruları" konu başlığı altında "Bayrak töreninde kurallara uyan öğrenci hangisidir?" (s.57) ifadesiyle yer almıştır. İstiklal 
Marşı'na saygı 1. Sınıf Hayat Bilgisi ders kitabı Okulumuzda Hayat Ünitesinde farklı yerlerde verilen cümlelerle tekrarlanmıştır' "Bayrağımız ve İstiklal Marşı'mız" konu başlı̆̆ı altında "İstiklal Marşı'mız söylenirken arkadaş1mızla konuşabiliriz." (s.28) D-Y testindeki ifadeyle, "İstiklal Marşı'mızı hep birlikte söylemeliyiz." (s.28) ifadesiyle yer almıştır. Değerlere saygı değeri Başkalarına saygı değeri 1. Sınıf Hayat Bilgisi ders kitabı Okulumuzda Hayat Ünitesinde "Sınıfımızda Neler Var?" konu başlığı altında "Sınıfımızda şeref köşesi bulunur. Şeref köşesi; Türk Bayrağı, İstiklal Marşı, Atatürk resmi ve Atatürk'ün Gençliğe Hitabesi'nden oluşur." (s.25) ifadesiyle yer almaktadır. "1. Sınıf Hayat Bilgisi ders kitabı Okulumuzda Hayat Ünitesinde "Kibar Olalım" konu başlığı altında "Daha kibar olabilirsin. Topu alırken izin almalısın" (s.45) ifadesiyle yer almıştır.

Görsellerde ise 18 ayrı yerde saygı değeri anlatılmaya çalışılmıştır. Saygı değerinin yer aldığı görselllerden örnek bir alıntı aşağıdaki gibidir:

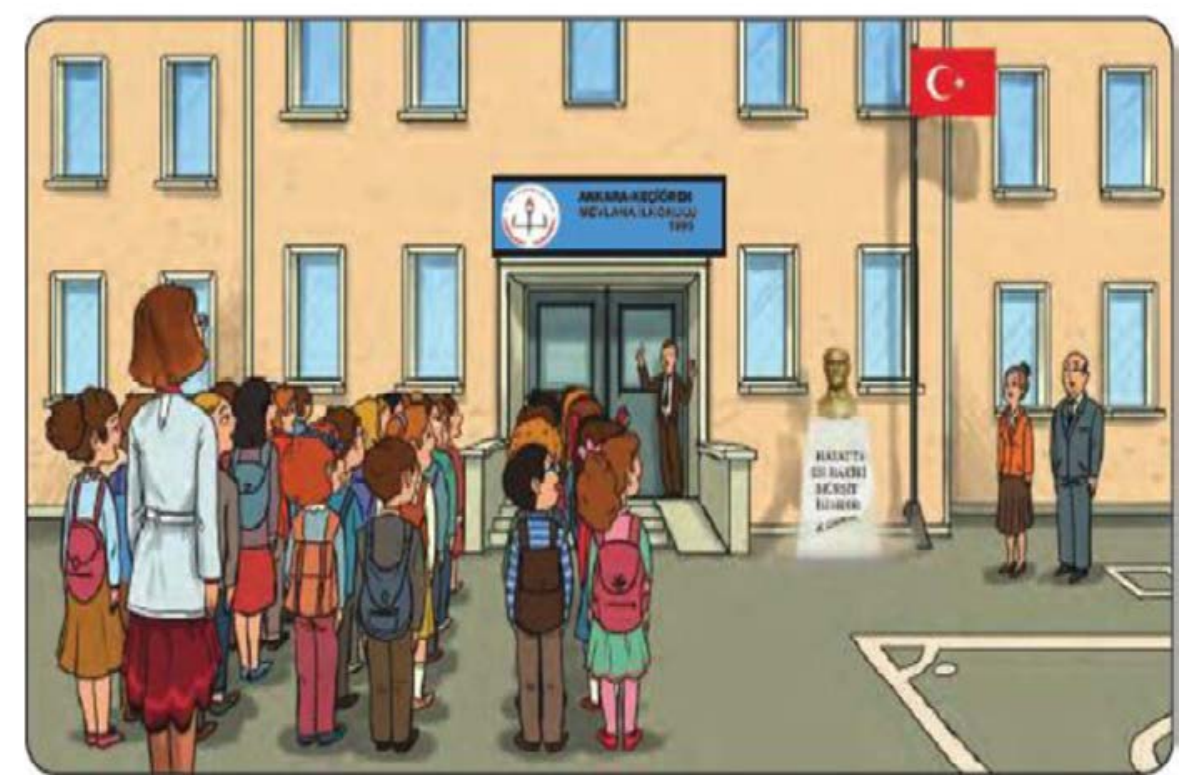

Öğrenciler, öğretmenler ve okulun bütün paydaşları İstiklal Marşı'mızı okurken milli marşına ve al bayrağına son derece saygılı davrandığı öğrencilere hissettirilmeye çalışılarak saygı değeri vurgulanmaya çalışılmıştır. 
Sevgi: Tablo 1'deki bulgulara göre, sevgi değeri 1. Sınıf Hayat Bilgisi ders kitabı Okulumuzda Hayat Ünitesindeki metinlerde yedi ayrı yerde bulunduğu düşünülmektedir. Sevgi değeri içerisinde bayrak sevgisi (4), okul sevgisi (1), insan sevgisi (1) ve vatan-millet sevgisi (1) alt değerleri yer almaktadır. Bayrak sevgisi değeri 1. Sınıf Hayat Bilgisi ders kitabı Okulumuzda Hayat Ünitesinde farklı yerlerde verilen cümlelerle tekrarlanmıştır. "Bayrağımız ve İstiklal Marşı'mız" konu başlığı altında "Okul bahçesine çıkarak bayrak törenini kurallarına uygun olarak canlandıralım." / "Bayrak töreninde etrafımıza bakabiliriz." (s.28) ifadeleriyle yer almıştır. Okul sevgisi değeri 1. Sınıf Hayat Bilgisi ders kitabı Okulumuzda Hayat Ünitesinde bir noktada değinilmiştir. "Yaşasın Okulumuz" konu başlığı altındaki "Okulum" adlı şarkının birinci kıtasında: "Okulumu pek çok, Pek çok severim.” (s.50) ifadesiyle yer almıştır. İnsan sevgisi değeri 1 . Sınıf Hayat Bilgisi ders kitabı Okulumuzda Hayat Ünitesinde bir noktada değinilmiştir. "Yaşasın Okulumuz" konu başlığı altında "Çocuklar, hepinizi çok seviyorum." (s.51) ifadesiyle yer almıştır. Vatan-millet sevgisi değeri 1. Sınıf Hayat Bilgisi ders kitabı Okulumuzda Hayat Ünitesindeki metinlerde söyle ifade edilmiştir: “Ünite Değerlendirme Soruları" konu başlığı altında "Atatürk resminin solunda ne var, Atatürk resminin üzerinde ne var?" (s.59) ifadeleriyle yer verilmiştir.

Sevgi değeri görsellerde ise 12 resimle ifade edilmiştir. Sevgi değerinin yer aldığı görselllerden örnek bir alıntı aşağıdaki gibidir:

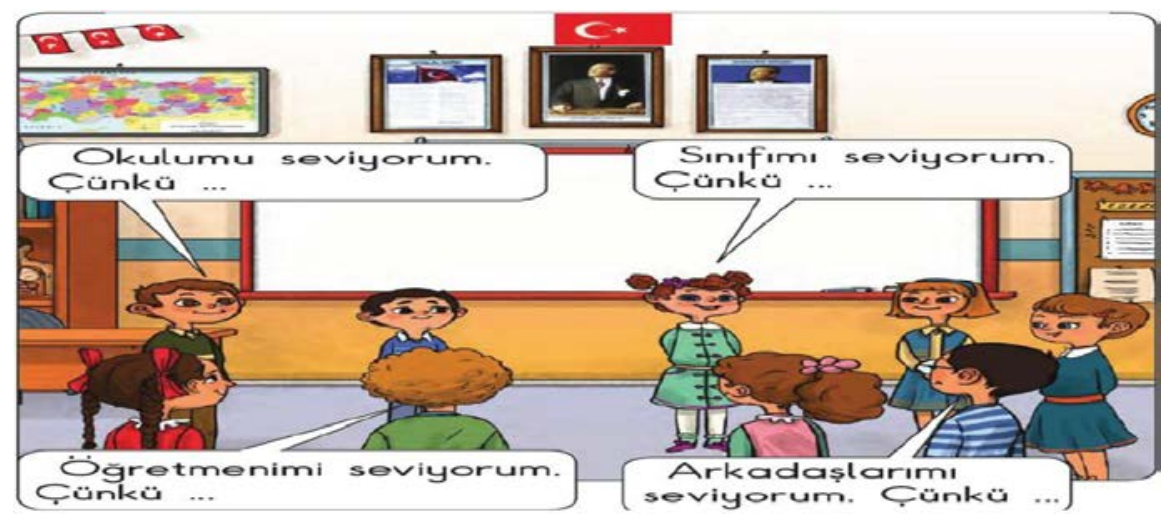

Görselde yer alan öğrenciler bütün farklılıklarıyla bir araya gelerek ülkesini, okulunu, öğretmenini ve arkadaşlarını neden sevdiğini ve niçin sevmesi gerektiğini açıklamaya çalışmaktadır. Aynı zamanda resmin arka planında 
yer alan şeref köşesinin varlığı ve öğrencilerin sevme nedenlerini açıklamaya çalışmalarını ifade etmeye çalışmaları ile sevgi (okul sevgisi, insan sevgisi, vatan sevgisi, bayrak sevgisi, Atatürk sevgisi...) değeri vurgulanmaya çalışılmıştır.

Sorumluluk: Tablo 1'deki bulgulara göre, sorumluluk değeri 1. Sınıf Hayat Bilgisi ders kitabı Okulumuzda Hayat Ünitesindeki dokuz farklı yerde bulunduğu düşünülmektedir. Sorumluluk değeri içerisinde üzerine düşen görevleri yerine getirme (9) alt değeri adı altında yer almaktadır. "Güvenli Yolları Biliriz" konu başlı̆̆ı altında "Servis hareket halindeyken ayağa kalkmamalıyız ve şoförün dikkatini dağıtacak hareketler yapmamalıyı. Emniyet kemerlerimizi mutlaka takmalıyız." (s.18)/ "Aşağıdaki resimde yanlış hareket eden kişileri bulalım. Yapılan yanlış hareketlerin hangi sonuçlara neden olabileceğini tartışalım." (s.20) ifadeleriyle ve "Ders Aracımı Seçiyorum" konu başlığı altında "Okul çantamızı hazırlarken nelere dikkat ederiz?" / "Okul çantamızı hazırlarken mutlaka ders programımıza bakmalıyı.." (s.53) ifadeleriyle yer almıştır. Sorumluluk değerinin beş farklı görselde de vurgulanarak bu değerin öğrencilere kazandırılmaya çalışıldığı düşünülmektedir. Sorumluluk değerinin yer aldığı görsellerden örnek bir alıntı aşağıdaki gibidir:

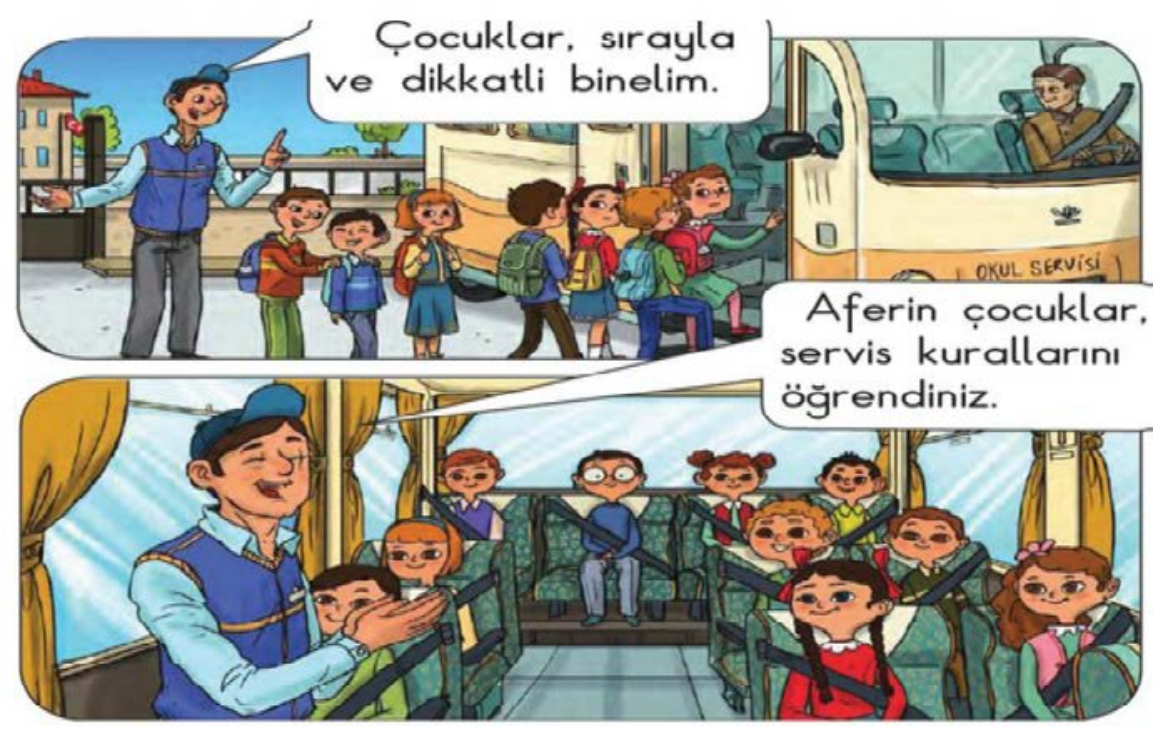


Görseldeki resimde öğrencilerin uymaları gereken kurallar, seyahat halindeki sorumlulukları üzerinde durularak öğrencilere sorumluluk değerinin kazandırılmaya çalışıldığı ve sorumluluk değerinin ele alındığı anlaşılmaktadir.

Vatanseverlik: Tablo 1'deki bulgulara göre, vatanseverlik değeri 1. Sınıf Hayat Bilgisi ders kitabı Okulumuzda Hayat Ünitesindeki metinlerde dört farklı yerde bulunduğu düşünülmektedir."Sınıfımızda Neler Var?" konu başlığ altında "Atatürk'ün gençlere seslenişidir." (s.25) ifadesiyle ve "Bayrağımız ve İstiklal Marşı'mız" konu başlı̆̆ı altında "Bayrağımız ve İstiklal Marşı'mızı okul dışında nerelerde duyuyoruz." / "Bayrağımız ve İstiklal Marşı'mız bağımsızlığımızın sembolüdür. Bu nedenle bayrağımıza ve İstiklal Marşı'mıza sayg1 göstermeliyiz. Bayrak töreninde yüzümüzü bayrağımıza dönmeliyiz ve konuşmamalıyız." (s.27) ifadeleriyle yer almaktadır. Vatanseverlik değerinin beş farklı görselde de vurgulanarak bu değerin öğrencilere kazandırılmaya çalışıldığı düşünülmektedir. Vatanseverlik değerinin yer aldığı görsellerden örnek bir alıntı aşağıdaki gibidir:

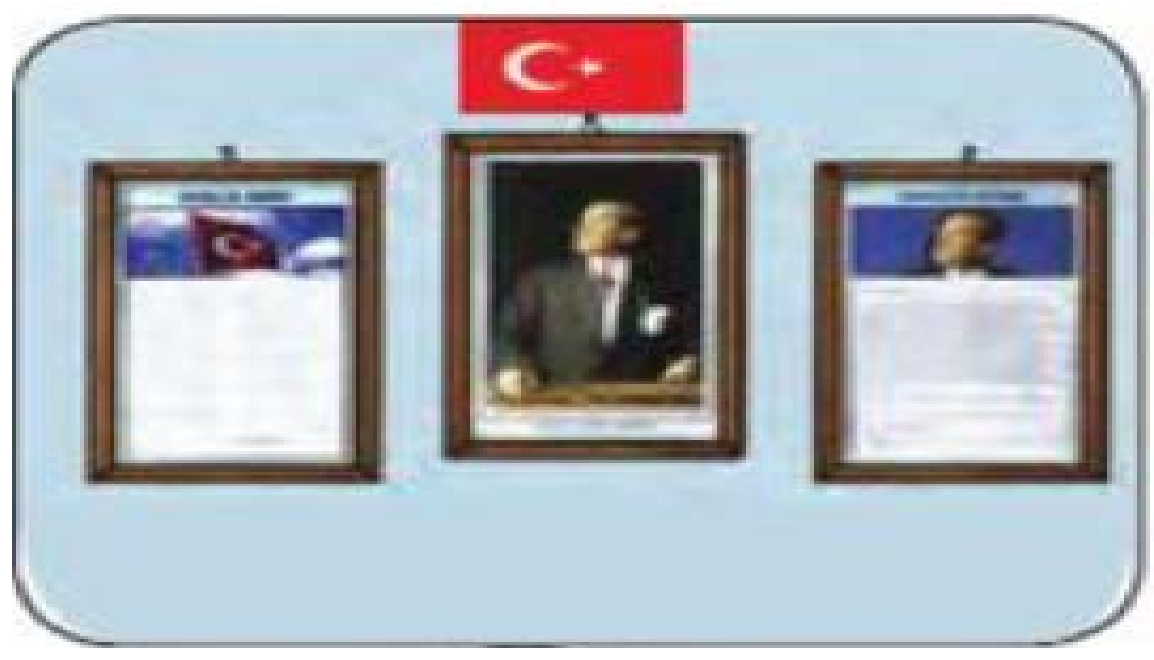

Görselde yer alan şeref köşesi, şeref köşesinin içinde yer alan milli marşımız, bayrağımız, Gençliğe Hitebe ve Atatürk portresi ile vatanseverlik değerine vurgu yapıldığı düşünülmektedir. 
Yardımseverlik: Tablo 1'deki bulgulara göre, yardımseverlik değeri 1. Sınıf Hayat Bilgisi ders kitabı Okulumuzda Hayat Ünitesindeki metinlerde beş farklı yerde bulunduğu düşünülmektedir. Yardımseverlik değeri içerisinde ihtiyacı olana yardım etme (5) alt değeri adı altında yer almaktadır."Güvenli Yolları Biliriz" konu başlığı altında "Merhaba Fatma Teyze, poşetleri taşımana yardım edeyim." (s.21) ifadesiyle, "İyi ki Onlar Var" konu başlı̆̆ altında "Öğretmenim, arkadaşım dizini yaraladı. Yardım eder misiniz?" / "Selahattin Amca, lavabo taşmış. Yardım eder misiniz?" (s.35)/ "Ayşe sütünü yanlışlıkla koridora döktüğünde kimden yardım istemelidir?" (s.37) ifadeleriyle, "Ünite Değerlendirme Soruları" konu başlığı altında "Lavabonun taştığını gördüğümüzde hangi okul çalışanından yardım isteriz" (s.58) ifadesiyle yer almaktadır. Yardımseverlik değerinin iki farklı görselde de vurgulanarak bu değerin öğrencilere kazandırılmaya çalışıldığı düşünülmektedir. Yardımseverlik değerinin yer aldığı görsellerden örnek bir alıntı aşağıdaki gibidir:

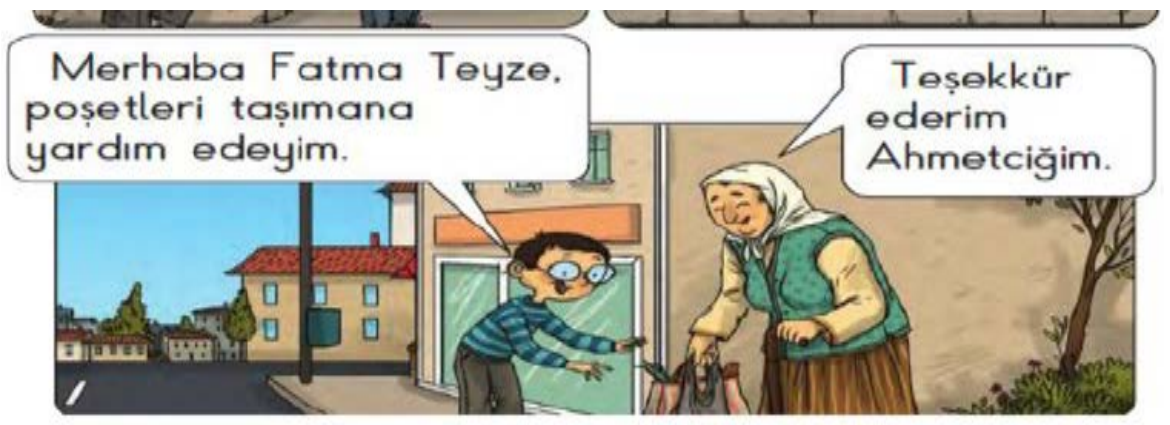

Bu görselde yaşlı bir teyzeye yardım eden bir çocuk resmedilmiştir. Görsel ifadeden anlaşıldığı üzere yardım eden çocuğun ve yardım edilmeyi kabul eden yaşlı teyzenin bu durumdan son derece mutlu olduğu yüzlerindeki tebessümden anlaşılmaktadır. Yardım etmenin insanları mutlu edeceği yukarıdaki kareyle öğrencilere anlatılmaya ve hissettirilmeye çalışılmıştır. 


\section{Hayat Bilgisi Öğretim Programı Ve Okulumuzda Hayat Ünitesinde Yer Alan Değerlerin Karşılaştırılması}

Hayat Bilgisi öğretim programında yer alan değerlerin içerisinden 12 farklı değerin İlkokul 1. Sınıf Hayat Bilgisi ders kitabı Okulumuzda Hayat Ünitesi'ndeki görsellerde veya metinlerde yer aldığ1 tespit edilirken ünite kazanımlarında 5 farklı değerin [duyarlılık $(f=3)$ (HB.1.1.2, HB.1.1.11. ve HB.1.1.16. numaralı kazanım), güven ( $f=1)$ (HB.1.1.3. numaralı kazanım), sayg $(f=1)$ (HB.1.1.6. numaralı kazanım), temizlik ( $f=1$ ) (HB.1.1.8. numaralı kazanım), yardımseverlik ( $f=1$ ) (HB.1.1.10. numaralı kazanım)] yer aldığı düşünülmektedir. Programda ve İlkokul 1. Sınıf Hayat Bilgisi ders kitabı Okulumuzda Hayat Ünitesi'ndeki görsellerde yer alan değerler Tablo 3'te sunulmuştur.

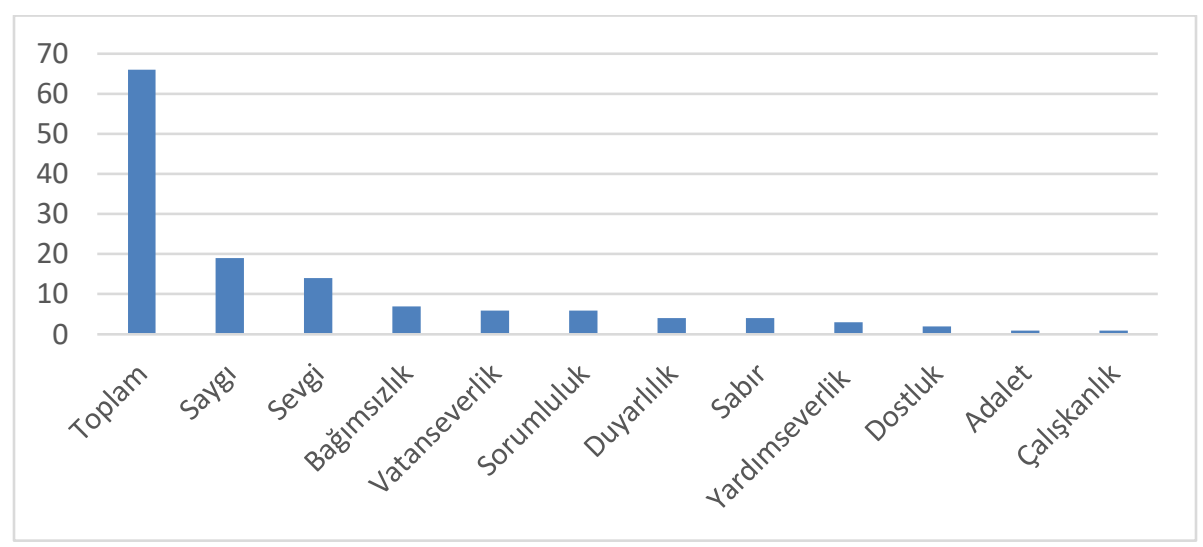

Tablo 3'te görüldüğüu üzere programla uyumlu olarak İlkokul 1. Sınıf Hayat Bilgisi Ders Kitabı Okulumuzda Hayat Ünitesi'ndeki görsellerde yer alan değerler tespit edilen sıklık sırasıyla saygı $(f=19)$, sevgi ( $f=14)$, bağımsızlık $(f=7)$, vatanseverlik $(f=6)$, sorumluluk $(f=6)$, $\operatorname{duyarl} 1 \mathrm{l1k}(f=4)$, sabır $(f=4)$, yardım$\operatorname{severlik}(f=3)$, $\operatorname{dostluk}(f=2)$, adalet $(f=1)$ ve çalışkanlık $(f=1)$ değerleridir.

Ek olarak adalet, dürüstlük, öz denetim ve sabır kök değerlerinin metinlerde yer almadığı, adalet ve sabır değerlerinin ise sadece görsellerde yer aldığ1 tespit edilmiştir. Bununla birlikte programda yer almamasına rağmen, İlkokul 1. Sınıf Hayat Bilgisi ders kitabı Okulumuzda Hayat Ünitesi'ndeki 
görsellerde ve metinlerde yer alan bazı değerlerin vurgulandığ 1 tespit edilmiştir. Bu değerler sıklık sırasıyla nezaket $(f=9)$, öz denetim $(f=9)$, temizlik $(f=8)$, selamlaşma $(f=5)$, hoşgörü $(f=3)$ ve empati $(f=1)$ değerleridir.

\section{Sonuç ve Öneriler}

MEB (2018) İlkokul çağındaki öğrencilere birey, toplum ve doğa ekseninde temel bilgi, beceri ve değerler kazandırmayı hedefleyen Hayat Bilgisi dersi Öğretim Programı çerçevesinde öğrencilere kazandırılması hedeflenen özel hedefleri arasında aile ve toplumun temel değerlerine sahip olmasının yanında millî, manevi ve insani değerleri yaşantısal hâle getirmesini belirtmiştir ${ }^{1}$.

Milli Eğitim Bakanlığı tarafından basılan 1. Sınıf Hayat Bilgisi ders kitabı Okulumuzda Hayat Ünitesi'nde yer alan metin ve görsellerin incelenmesi amacıyla yapılan bu araştırmanın sonucunda 1. Sınıf Hayat Bilgisi Ders Kitabı Okulumuzda Hayat Ünitesi'nde yer alan metinlerin programda yer alan değerleri tam olarak aktaramadığı; ancak kitapta yer alan metin ve görsellerin bu açığı kapattığını söylemek mümkündür.

İlkokul 1. Sınıf Hayat Bilgisi ders kitabı Okulumuzda Hayat Ünitesi'nde yer alan değerlerin sayısal verilerine ilişkin elde edilen sonuçlar; saygı, güven, sevgi, sorumluluk, yardımseverlik, duyarlılık, vatanseverlik, bağımsızlık, çalışkanlık, sabır ve dostluk değerlerinin sıklıkla tekrarlandığını göstermektedir. Ünite içerisinde en fazla saygı, sevgi ve sorumluluk değerleri yer alırken; en az çalışkanlık, adalet, sabır ve dostluk değerlerinin olduğu tespit edilmiştir. Bu çalışma ile birebir örtüşmese de Hayat bilgisi programını ve ders kitaplarını farklı kademelerde inceleyen bir kaç çalışma mevcuttur. Örneğin, Öztürk ve Özkan (2018) bu alanda yapılan çalışmaların ilk örneklerinden birini gerçekleştirmiştir. 3. Sınıf Hayat bilgisi ders kitaplarındaki metin ve görsellerin değerler açısından incelendiği çalışma sonucunda, incelenen ders kitabında en çok yer alan değerlerin sevgi, saygı ve hoşgörü, en az yer alan değerin ise misafirperverlik, estetik ve doğa sevgisi olduğunu ortaya konmuştur. Sıklıkla vurgulanan değerler açısından (sevgi ve saygı) eldeki çalışma bu çalışma sonuçları ile tutarlılık göstermektedir.

${ }^{1}$ mufredat.meb.gov.tr 
Bununla birlikte güven, vatanseverlik, bağımsızlık, çalışkanlık, sabır ve dostluk değerleri tek boyutta ele alınırken; duyarlılık değeri (toplumsal duyarlılık ve kültürel mirasa duyarlılık) iki alt değer, saygı değeri (farklılıklara saygı, bayrağa saygı, İstiklal Marşı'na saygı, değerlere saygı ve başkalarına saygi) beş alt değer, sevgi değeri (bayrak sevgisi, okul sevgisi, insan sevgisi ve vetan-millet sevgisi) dört alt değer, sorumluluk değeri (üzerine düşen görevleri yerine getirme) tek alt değerde ve yardımseverlik değerinin (ihtiyacı olana yardım etmek) tek alt değerde konumlandırıldığı tespit edilmiştir.

Araştırmanın ikinci alt probleminde Hayat Bilgisi öğretim programında yer alan değerler ile 1. Sınıf Okulumuzda Hayat Ünitesinde tespit edilen değerler karşılaştırılmıştır. Hayat Bilgisi öğretim programında öğrencilere aktarılması hedeflenen kök değerler incelendiğinde adalet, dostluk, dürüstlük, öz denetim, sabır, saygı, sevgi, sorumluluk, vatanseverlik, yardımseverlik olmak üzere on değer verilmekteyken; ünite incelemesi sonucunda adalet, dürüstlük, öz denetim ve sabır kök değerlerinin metinlerde yer almadığı; adalet ve sabır değerlerinin ise sadece görsellerde bulunmadığı tespit edilmiştir. Kök değerlerin genel anlamda ünite içerisinde planlı ve programlı bir şekilde yer almadığı ve metinlerin içerisinde belirli sayıda ve belirli bir düzen ile dağılım göstermediği ortaya konulmuştur. Metin içerisindeki değerler incelendiğinde bazı metinlerde hiçbir değer ifade edilmezken; aynı metin içinde birden fazla değer ifade eden yapılar olduğu tespit edilmiştir. Bunun yanı sıra programda belirtilmediği halde kazanımlar, metinler ve görsellerde yer alan birçok değerin olduğu saptanmıştır.

Balık (2016) ders ve masal kitaplarını değerler eğitimi açısından incelediği çalışmasında, ders kitaplarının Hayat Bilgisi dersi öğretim programında yer alan bütün değerleri kapsadığını belirtmiştir. Ancak bu değerlerin dışında kalan birçok değeri barındırmadığı gerekçesiyle ders kitaplarının Hayat Bilgisi dersi öğretim programında yer alan değerleri aktarmada yeterli olmakla beraber bunların dışında kalan değerleri aktarmakta yetersiz olduğunu ifade etmiştir.

Araştırmanın çarpıcı sonuçlarından bir tanesi de her ne kadar bu çalışmanın temel sınırlılığı kapsamında yer alsa da Hayat Bilgisi dersi kitabında yer alan sadece bir ünitede metin ve görsellerde sıklıkla tekrarlanan 13 değer ifadesinin tespitidir. Belirlenen ders süresi dahilinde soyut olan (bağımsızlık, adalet, duyarlılık vb.) değerlerin ve değer ifadelerinin her birinin ya da kaç 
tanesinin öğretmenler tarafından nasıl etkili bir şekilde verileceği ve davranışa dönüşümünün tespit edileceği belirsizliklere yol açmaktadır.

Demir ve Demirhan İşcan (2007) değerlerin öğretim programlarında ayrı bir başlık altında yer almadığ 1 dönemde yaptıkları çalışmalarında, ilköğretim 1., 2. ve 3. sınıf hayat bilgisi dersi öğretim programı ile öğrenci ders ve çalışma kitaplarındaki değerleri incelemişler ve çalışma sonucunda değerlerin nasıl öğretileceği ve değerlendirileceğine ilişkin yeterli ve uygun çalışmaların olmadığını saptamışlardır. Ek olarak öğrenci ders ve çalışma kitaplarında ise özellikle değerlendirme boyutunda değerlerin öğretimine ilişkin etkinliklerin değerleri kazandırmada yetersiz kaldığını ifade etmişlerdir. Thornberg (2008) çalışmasında da değerler eğitimi uygulamalarına yönelik öğretmen algılarını tespit ederek, bu konu hakkındaki yeterliliklerini ve profesyonelliklerini tespit etmeyi amaçlamış ve çok manidar sonuçlara ulaşmıştır. Bulgular değerler eğitiminin plansız yapıldığı, değerler eğitiminin öğrencilerin olağan davranışlarına göre yapıldığı bunun da bilinçsizce yapıldığı, öğretmenlerin değerler eğitimine yönelik yeterli bilgilerinin olmadığını göstermektedir.

Bunlara ek olarak program öğelerinden ölçme-değerlendirme boyutu incelendiğinde, etkinliklerde ve değerlendirme sorularında genel olarak bilişsel boyutun ölçülmeye çalışıldığı, duyuşsal alan ve devinişsel alan (performans gösterme) alanlarına yönelik ders içeriği ve değerlendirme sorularının neredeyse hiç yer almadığını söylemek mümkündür. Ders kitaplarındaki metin ve görsellerde, program bünyesindeki kazanımlarda yer alan değerlerin sadece sayısal anlamda olması yeterli görülmemektedir; bu değerlerin etkinliklerde nasıl kazandırılacağı, öğrencilerin bu değerlere neden önem verip kazanması gerektiği, bilişsel anlamda kazandırılan değerlerin performans haline nasıl getirileceği gibi hususlara da değinilmesi ve örneklendirilmesi gerekmektedir. Bu sebeple programın önemli bir bileşeni olan ölçme-değerlendirme öğesinin de metin sonrası yansitıcı değerlendirme soruları ya da proje/performans görevleriyle desteklenmemesi eksiklik olarak ifade edilebilir. Demir ve Demirhan İşcan (2007) ve Yaşaroğlu (2018), 2015, 2017 ve 2018 Hayat bilgisi öğretim programlarını değerler açısından incelediği çalışmasında özellikle ölçme-değerlerlendirme boyutunun eksikliğine vurgu yaparak değerlerin amaçlanması, kazandırılmasında özen gösterilmesi gerektiği kadar, nasıl ölçülmesi gerektiği konusunda da öğretmenlere rehberlikte bulunulmalıdır şeklinde bir öneri getirmişlerdir. 


\section{Öneriler}

Çalışma sonuçlarına dayalı olarak, araştırmacılara ve uygulayıcılara aşağıdaki öneriler geliştirilmiştir:

Araştırmacılara yönelik olarak, Hayat Bilgisi dersi kapsamında farklı kitaplar, üniteler ve kademelerdeki metin ve görseller değerler açısından incelenerek karşılaştırma yapılması önerilebilir. Bu konuda programların uygulayıcıları olan öğretmenlerin de görüşleri alınarak görüşme ve gözlem yoluyla derinlemesine bir inceleme yapılması sağlanabilir.

\section{Uygulayıcılara yönelik olarak;}

Ünitelere göre değerlerlerin konumlandırılması ve nicelik anlamında öğretmenlere kolaylık sağlaması açısından oranlı bir şekilde dağıtılması ve kitaplarda bu yönde bir düzenleme yapılması gerekmektedir.

Değer öğretimine ilişkin tüm hususlar örtük program aracılığıyla öğretmenlere bırakılmış durumdadır. Bu açıdan öğretim programında yer alan ve kitaplarda yer almayan değerlerin telkin, dolaylı öğretim ve rol model olma yoluyla öğretilebileceği varsayılsa da, ders kitaplarının öğretmenlere yol gösterici konumda olması önemlidir. Dolayısıyla Hayat Bilgisi ders kitaplarında metin ve görsellerle ilgili sorular ve etkinlikler değer öğretimi için kullanılabilecek aktif yaklaşım ve yöntemler (ahlaki ikilem yaklaşımı, değer bilinçlendirme yaklaşımı, örnek olay yöntemi vb.) kullanılarak etkinlikler tasarlanıp hem öğrenme öğretme süreci hem de ölçme değerlendirme boyutunda kazanımların nasıl davranışa dönüşeceği hususlarında çağdaş uygulamalarla kitaplara entegre edilebilir. 


\title{
EXTENDED ABSTRACT
}

\section{Investigation of the Values in the Life Unit in Our First Class Life Science Course}

\author{
Ümit Gözel-Beste Dinçer \\ Aydın Adnan Menderes University
}

It is a fact that the changes and developments experienced at a dizzying speed in the technology, science and communication sectors in the global world have deeply affected human life and social structure.

It is possible to say that we live in an age that can cross the borders of the current world in seconds. However, it is a fact that this situation brings some problems with the living conditions such as adopting the values and transferring them to the new generation in school settings.

Within the scope of this study, it was aimed to examine the text and visuals in the Life Unit in our School in the 1st Class Life Science course in terms of values. In line with this basic purpose, it was aimed to determine the presence and frequency of the values given in the scope of the Life Science course in the text and images, and to determine their distribution and rates within the unit.

The study group of this research was the first Class Life Science Textbook within the scope of the curriculum renewed in the 2017-2018 Academic Year and by adopting a qualitative research design, the data were analyzed by document analysis method based on the analysis of written and visual materials covering information about the purpose of the research.

As a result of this research carried out to examine the text and images in the Life Unit in our School, the $1^{\text {st }}$ Class Life Science coursebook published by the Ministry of National Education, the $1^{\text {st }}$ Class Life Science Textbook does not fully convey the values in the program in the Life Unit in our School; however, it is possible to say that the text and images in the book closed this gap. 
Results obtained regarding the numerical data of the values in the Life Unit in our School; the values of respect, trust, love, responsibility, benevolence, sensitivity, patriotism, independence, diligence, patience, and friendship were frequently repeated.

However, while the values of trust, patriotism, independence, diligence, patience, and friendship were considered in one dimension, sensitivity value (social sensitivity and sensitivity to cultural heritage) were two sub-values, respect value (respect for differences, respect for the flag, respect for the National Anthem, respect for values and respect for others) five lower values, love value (flag love, school love, human love, and patriot-nation love) four lower values, responsibility value (fulfilling their duties), single value and benevolence value (helping the needy) were located at a single lower value.

In the second sub-problem of the study, the values in the Life Studies curriculum were compared with the values determined in the Life Unit in our $1^{\text {st }}$ grade school. When the root values that were aimed to be transferred to students in the Life Science curriculum are examined, ten values were given as justice, friendship, honesty, self-control, patience, respect, love, responsibility, patriotism, and benevolence; the root values of justice, honesty, self-control, and patience were not included in the texts as a result of the unit review; it was determined that the values of justice and patience were not only in the images. It was demonstrated that the root values were not included in the unit in a planned and programmed manner in general and that the texts were not distributed in a certain number and a certain order. When the values in the text were examined, no value was expressed in some texts; it was determined that there were structures that express more than one value in the same text. Also, it was determined that there are many values in the achievements, texts, and images, although they were not specified in the program.

Based on the results of the study, the following recommendations have been developed for researchers and practitioners:

For the researchers: Within the scope of the Life Science lesson, it may be suggested to analyze the text and images in different books, units, and levels in terms of values. By taking the opinions of the teachers who are the practitioners of the programs on this subject, an in-depth analysis can be made through interview and observation. 
For practitioners: All aspects of teaching value are left to teachers through the implicit program. In this respect, although it is assumed that the values in the curriculum and not included in the books can be taught through suggestion, indirect teaching, and role modeling, the textbooks must be instructive. Therefore, the questions and activities related to text and visuals in Life Science textbooks are designed using active approaches and methods (moral dilemma approach, value awareness approach, case study method, etc.) that can be used to learn how the acquisitions in the learning-teaching process and measurement-evaluation dimension. It can be integrated into books with contemporary applications in terms of its transformation.

\section{Kaynakça / References}

Abu, L., Mockhtar, M., Hassan, Z. and Suhan, S. Z. D. (2015). How to develop character of Madrassa Students in Indonesia. Journal of Education and Learning. 9(1), 7986.

Akbaş, O. (2008). Değer eğitimi akımlarına genel bir bakış. Değerler Eğitimi Dergisi, 6(16), 9-27.

Ak Tefek, F. (2016). Hayat bilgisi dersindeki değerlere yönelik öğrenci görüşleri ve edinim durumları. Yayımlanmış Yüksek Lisans Tezi. Ahi Evran Üniversitesi, Sosyal Bilimler Enstitüsü, Kırşehir.

Akyol, P. (2018). İlkokul üçünciu smmf hayat bilgisi dersi kulavuz kitabmdaki okul heyecanmm temasında yer alan etkinliklerin ara disiplin kazanımlar açısından öğretmen görüşlerine göre değerlendirilmesi. Yayimlanmamiş Yüksek Lisans Tezi. Çukurova Üniversitesi, Sosyal Bilimler Enstitüsü, Adana.

Aslan, S. and Aybek, B. (2019). The value of helpfulness: An analysis of the $4^{\text {th }}$ grade primary school students' viewvs and their drawings. International Online Journal of Educational Sciences, 11 (5), 106-118.

Bahçe, A. (2010). Hayat bilgisi öğretiminde değerlerin kazandınlma düzeylerinin öğretmen görüşlerine göre değerlendirilmesi. Yayımlanmamış Doktora Tezi. Selçuk Üniversitesi Eğitim Bilimleri Enstitüsü, Konya.

Bal, Ö. (2019). Hayat bilgisi dersi değerler eğitiminde örnek olay yöntemi: Bir eylem araştırması. Yayimlanmamiş Yüksek Lisans Tezi. Eskişehir Osmangazi Üniversitesi, Eğitim Bilimleri Enstitüsü, Eskişehir.

Balı, Z. D. (2016). Hayat bilgisi öğretim programındaki değerler bakımından hayat bilgisi ders kitaplarn ile yüz temel eser listesindeki ulusal masallarn karşlaştırlması. Yayımlanmamış yüksek lisans tezi. Yüzüncü Yıl Üniversitesi, Eğitim Bilimleri Enstitüsü. Van. 
Bayırlı, H. (2018). Hayat bilgisi dersi bağlaminda değerler eğitimi: aile birliğine önem verme. Yyaımlanmamış Yüksek Lisans Tezi. Sakarya Üniversitesi, Eğitim Bilimleri Enstitüsü, Sakarya.

Baysal, Z. N., Tezcan, Ö. ve Araç, K. E. (2018). Türkiye ve Almanya-Hamburg hayat bilgisi dersinin karşılaştırılması: Genel bir bakış. Kuramsal Eğitim Bilim, 11(1), $117-134$.

Bowen, G. A. (2009). Document analysis as a qualitative research method. Qual Res J, 9, $7-40$.

Bölük, E. (2018). Çizgi filmlerde yer alan değerlerin ilkokul hayat bilgisi öğretim programinda yer alan değerler çerçevesinde incelenmesi. Yayımlanmamış Yüksek Lisasn Tezi. Mustafa Kemal Üniversitesi, Sosyal Bilimler Enstitüsü, İstanbul.

Brady, L. (2011). Teacher values and relationship: Factors in values education. Australian Journal of Teacher Education, 36(2), 5.

Candan, D. G., ve Ergen, G. (2014). 3. sinf hayat bilgisi ders kitaplarınin temel evrensel değerleri içermesi bakımından incelenmesi. Uşak Üniversitesi Sosyal Bilimler Dergisi, 7(1), 134-161.

Creswell, J. (2012). W.(1994). Research design: Qualitative and quantitative approaches. Thousand Oaks, 88(2), 207.

Çanak, S. (2019). Simf öğretmenlerinin hayat bilgisi dersinde öğrencilere demokrat değerlerin kazandirlmasina yönelik görüşleri. Yayımlanmamiş Yüksek Lisans Tezi. Tokat Gaziosmanpaşa Üniversitesi, Eğitim Bilimleri Enstitüsü, Tokat.

Dally, K. (2010). A teacher's duty: An examination of the short-term impact of values education on Australian primary school teachers and students. In International research handbook on values education and student wellbeing (p. 503-520). Springer, Dordrecht.

Demir, F. (2018). Değer öğretimi yaklaşımlarna göre hayat bilgisi dersinde değerler eğitimi. Yayımlanmamış Doktora Tezi. İnönü Üniversitesi, Eğitim Bilimleri Enstitüsü, Malatya.

Demir, K. ve Demirhan İşcan, C. (2007). Hayat bilgisi dersinde değerler ve değerler eğitimi. 1. Ulusal İlköğretim Kongresi. 15-17 Kasım 2007, Hacettepe Üniversitesi, Ankara.

Dill, J. S. (2007). Durkheim and Dewey and the challenge of contemporary moral education. Journal of moral education, 36(2), 221-237.

Dinçer, B. ve Gözel, Ü. (2018). İlkokul programlarında (1-4) yer alan ve kazandırılması hedeflenen değerlere ilişkin sınf öğretmenlerinin ve öğrenci velilerinin görüşlerinin incelenmesi. Değerler Eğitimi Dergisi, 17(38), 207-234. 
Erylmaz, M. A. (2016). Sinfföğretmenleriinin ü̧̈üncü sinf hayat bilgisi derslerinde değerler eğitimi uygulamalarnna ilişkin görüşleri. Yayımlanmamış Yüksek Lisans Tezi. Gazi Üniversitesi, Eğitim Bilimleri Enstitüsü, Ankara.

Glesne, C. ve Peshkin, A. (1992). Becoming qualitative researchers an introduction. London: Longman Group Ltd.

Gözel, Ü. (2018). Hayat bilgisi dersi öğretim programmnn değerler eğitimi açısından öğretmen görüşlerine göre değerlendirilmesi. Yayımlanmamış Yüksek Lisans Tezi. Aydın Adnan Menderes Üniversitesi, Sosyal Bilimler Enstitüsü, Aydın.

Gündüz, M. (2014). Illköğretim 3. Sinf hayat bilgisi dersinde "sorumluluk" değerinin proje tabanl öğrenme yaklaşım ile öğretiminin akademik başarı ve tutuma etkisi. Yayımlanmamış Doktora Tezi. Gazi Üniversitesi, Eğitim Bilimleri Enstitüsü, Ankara.

Güzel, D. (2013). 3. Sinff hayat bilgisi ders kitaplarmın temel eorensel değerleri içermesi baktmından incelenmesi. Yayımlanmamış Yüksek Lisans Tezi. Çanakkale Onsekiz Mart Üniversitesi, Eğitim Bilimleri Enstitüsü, Çanakkale.

Halil, E. (2003). Temel insani değerlerin kazandırılmasında bir yaklaşım: Karakter eğitimi programları. Değerler eğitimi dergisi, 1(1), 79-96.

Hashim, C. N. ve Langgulung, H. (2008). Islamic religious curriculum in Muslim countries: The experiences of Indonesia and Malaysia. Bulletin of Education \& Research, 30(1), 1-19.

Kale, M. (2015). Hayat bilgisi ders kitaplannda yer alan değerlerin içerik analizi. Yayımlanmamış Yüksek Lisans Tezi. Gazi Üniversitesi, Eğitim Bilimleri Enstitüsü, Ankara.

Koç, M. A. (2020). Hayat bilgisi dersi kapsamında değerler eğitimi üzerine bir araştırma: beklentiler, uygulamalar ve öneriler. Yayımlanmamış Doktora Tezi.Istanbul Üniversitesi, Lisansüstü Eğitim Enstitüsü, İstanbul.

Köylü, M. (2016). Teoriden pratiğe değerler eğitimi. Ankara: Nobel Yayıncllk.

Kulaksızoğlu, A. ve Dilmaç, B. (2000). İnsani değerler eğitimi programı. Atatürk Eğitim Fakültesi Eğitim Bilimleri Dergisi, 12, 199-208.

Kurt, Ö. (2019). 6-10 Yaş çocuk öykü kitaplarnmn meb 2018 hayat bilgisi öğretim programmda bulunan değerler yönünden incelenmesi. Yayımlanmamış Yüksek Lisans Tezi. Dukuz Eylül Üniversitesi, Eğitim Bilimleri Enstitüsü, İzmir.

Küçük, F. (2016). Birleştirilmiş ve müstakil stnuff ögrencilerinin hayat bilgisi öğretim programındakiözgüven, yardımseverlik ve yeniliğe açklıkdeğerlerinin kazanma düzeyleri. Yayımlanmamış Yüksek Lisans Tezi. Bartın Üniversitesi, Eğitim Bilimleri Enstitüsü, Bartın.

Marshall, J. C., Caldwell, S. D. ve Foster, J. (2011). Moral education the character plus Way®. Journal of Moral Education, 40(1), 51-72. 
Maxwell, J. A. (1992). Understanding and Validity in Qualitative Research. Harvard Educational Review, 62, 9791000.

MEB. (2005). İköğretim 1, 2 ve 3. sinfflar hayat bilgisi dersi program. Ankara.

MEB. (2009). Ilköğretim 1, 2 ve 3. simılar hayat biloisi dersi öğretim programı ve kılavuzu. Ankara.

MEB. (2015). Ilkokul hayat bilgisi dersi, (1, 2 ve 3. simılar) öğretim programı. Ankara.

MEB, (2017). Hayat bilgisi dersi öğretim programı. (İlkokul 1, 2, ve 3. stnıflar). Ankara.

MEB. (2018). Hayat bilgisi dersi öğretim programı, (ilkokul 1, 2 ve 3. sinıflar). Ankara.

Miles, M.B. ve Huberman, A.M. (1994). An expanded sourcebook qualitative data analysis. London: Sage Publications.

Narin, D. (2007). İköğretim hayat biloisi dersi öğretim programı'nın vatandaşlık bilgi, beceri ve değerlerini kazandırmasına ilişkin öğretmen görüşleri. Yayımlanmamış Yüksek Lisans Tezi. Anadolu Üniversitesi, Eğitim Bilimleri Enstitüsü, Eskişehir.

Noddings, N. (1994). Conversation as moral education. Journal of Moral Education, 23(2), 107-118.

Özkan, Z. S. (2017). Hayat bilgisi ders kitaplarnndaki metin ve görsellerin değerler açısından incelenmesi. Yayımlanmamış Yüksek Lisans Tezi, Ordu Üniversitesi Sosyal Bilimler Enstitüsü, Ordu.

Özleşmiş, N. (2019). İlkokul hayat bilgisi dersi kapsamında değerler eŏitimi uygulamalarna ilişkin öğretmen görüşlerinin incelenmesi. Yayımlanmamış Yüksek Lisans Tezi, Marmara Üniversitesi, Eğitim Bilimleri Enstitüsü, İstanbul.

Öztürk, T. veÖzkan, Z. S. (2018). Hayat bilgisi ders kitaplarındaki metin ve görsellerin değerler açısından incelenmesi. Eğitimde Nitel Araştırmalar Dergisi, 6(1), 172204. DOI: 10.14689/issn.2148-2624.1.6c1s8m.

Raihani. (2011). A whole-school approach: A proposal for education for tolerance in Indonesia. Theory and Research in Education, 9(1), 23-39.

Roberts, P. ve Priest, H. (2006).Reliability and validity in research. Nursing Standard, 20, 41-45.

Roesgaard, M. H. (2011). 'The ideal citizen', globalization, and the japanese response: Risk, gate-keeping, and moral education in Japan.' Reimagining Japanese Education: borders, transfers, circulations, and the comparative.

Roesgaard, M. H. (2016). Moral education in Japan: Values in a global context. Taylor \& Francis.

Sever, B. (2015). İköğretim üçüncü sını hayat bilgisi programındaki değerlerin kazandırılması sürecinin öğretmen ve veli görüşlerine göre incelenmesi. Yayımlanmamış Yüksek Lisans Tezi. Çukurova Üniversitesi, Sosyal Bilimler Enstitüsü, Adana.

Sj, K. L. (1990). Moral education in Japan. Journal of Moral Education, 19(3), 172-181. 
Sude Ö.Z. (2017). Hayat bilgisi ders kitaplarnndaki metin ve görsellerin değerler açısından incelenmesi. Yayımlanmamı Yüksek Lisnas Tezi. Ordu Üniversitesi , Sosyal Bilimler Enstitüsü, Ordu.

Tezcan, M. (2003). Gizli müfredat eğitim sosyolojisi açısından bir kavram çözümlemesi. Türk Ë̆itim Bilimleri Dergisi, 1(1), 53-59.

Thornberg, R. (2008). The lack of Professional knowledge in values education. Teaching and Teacher Education, 24(7), 1791-1798.

Titus, D.N. (1994). Values Education in American Secondary School, Kutztown University Education Conferense, September 16. Kutztown, PA: ERIC Nr. ED381423

Tudball, L. (2007). Whole-school approaches to values education: Models of practice in Australian schools. Values Education and Lifelong Learning içinde (s. 395-410). Springer, Dordrecht.

Uçar, F. H. (2019). İkokul hayat bilgisi ve sosyal bilgiler ders kitaplarmda değerler eğitimi. Yayımlanmamış Yüksek Lisasn Tezi. Hatay Mustafa Kemal Üniversitesi, Sosyal Bilimler Enstitüsü, Hatay.

Ulusoy, K. ve Dilmaç, B. (2012). Değerler eğitimi. Ankara: Pegem Akademi.

Yaşaroğlu, C. (2013). Hayat Bilgisi dersi kazanımlarının değerler eğitimi açısından incelenmesi. Journal of Turkish Studies, 8(7), 849-849. https://doi.org/10.7827/TurkishStudies.4838

Yaşaroğlu, C. (2018). Öğretim programlarında değerler: Hayat Bilgisi dersi örneği. Anemon Muş Alparslan Üniversitesi Sosyal Bilimler Dergisi, 6(5), 725-733.

Yıldırım, A. veŞimşek, H. (2000). Sosyal bilimlerde nitel araştırma yöntemleri. (Gözden geçirilmiş 2. Baskı). Ankara: Seçkin Yayıncllk.

Yıldırım, A. ve Şimşek, H. (2002). Sosyal bilimlerde nitel araştırma yöntemleri. Ankara: Seçkin Yayıncllk.

Yıldırım, A., veŞimşek, H. (2005). Sosyal bilimlerde nitel araştırma yöntemleri. (Güncelleştirilmiş geliştirilmiş 5. Baskı). Ankara: Seçkin Yayınclık.

Ylldırım, A., ve Şimşek. H. (2006). Sosyal Bilimlerde Nitel Araştırma Yöntemleri. Ankara: Seçkin Yayıncllk.

Ylldırm, A., ve Şimşek, H. (2008). Sosyal Bilimlerde Nitel Araştırma Yöntemleri (6. Baskı).Ankara: Seçkin Yayıncilık.

Yıldırım, A. veŞimşek, H. (2011). Sosyal bilimlerde nitel araştırma yöntemleri (8. Baskı). Ankara: Seçkin Yayıncllk.

Yüksel, S. (2002). Yükseköğretimde eğitim ve öğretim faaliyetleri ve örtük program. Uludağ Üniversitesi Ĕ̆itim Fakültesi Dergisi, 15(1), 361-370.

Yüksel, S. (2004). Örtük program: Eğitimde saklı uygulamalar. Ankara: Nobel Yayın Dağtım. 
Yüksel, S. (2005). Örtük programn eğitim fakültesi öğrencilerinin öğretmenlik meslek derslerine yönelik düşüncelerindeki etkisi: Uludağ Üniversitesi Güzel Sanatlar Eğitimi Bölümü Örneği. 14. Ulusal Eğitim Bilimleri Kongresinde sunulmuş bildiri, Pamukkale Üniversitesi, Denizli. 29.06.2020 tarihinde http://mufredat.meb.gov.tr/adresinden erişilmiştir.

\section{Kaynakça Bilgisi / Citation Information}

Gözel, Ü. ve Dinçer, B. (2021). Birinci sınıf hayat bilgisi dersi okulumuzda hayat ünitesinde yer alan değerlerin incelenmesi. OPUS-Uluslararası Toplum Araştırmaları Dergisi, 17(34), 1063-1094. DOI: 10.26466/opus.760991 